\title{
Tricarbonylchromium Complexes of centro-Polyindans. Part 2.t Synthesis and Structure of Tricarbonylchromium Mono- and Bis-complexes of 4b,5,9b,10- Tetrahydroindeno[2,1-a]indene
}

\author{
Alberto Ceccon, ${ }^{a}$ Alessandro Gambaro, ${ }^{a}$ Francesco Manoli,, Alfonso Venzo, ${ }^{b}$ Paolo Ganis, \\ Dietmar Kuck ${ }^{d}$ and Giovanni Valle ${ }^{e}$ \\ a Dipartimento di Chimica Fisica, Via Loredan 2, 35131 Padova, Italy \\ ${ }^{b}$ CNR, Centro Studi Stati Molecolari Radicalici Eccitati, Via Loredan 2, 35131 Padova, Italy \\ c Dipartimento di Chimica, Università di Napoli, Via Mezzocannone 4, 80134 Napoli, Italy \\ ${ }^{d}$ Fakultät für Chemie, Universität Bielefeld, Universitätsstrasse 25, 4800 Bielefeld 1, Germany \\ e CNR, Centro di Studio sui Biopolimeri, Via Marzolo, 3, 35131 Padova, Italy
}

\begin{abstract}
The reaction of 4b,5,9b,10-tetrahydro[2,1-a] indene, $\mathrm{DIN}$, with $\mathrm{Cr}(\mathrm{CO})_{6}$ in $\mathrm{Bu}_{2} \mathrm{O}-\mathrm{THF}(9: 1)$ affords two mono-complexes with the inorganic unit bonded to the convex or to the concave side of the ligand, respectively. Prolonged reaction times cause the formation of two bis-complexes, bearing the two $\mathrm{Cr}(\mathrm{CO})_{3}$ units bonded both to the convex side of DIN in one case, and to the convex and to the concave side in the other. Steric factors seem important in the kinetic control of the stereochemistry of both the first and the second complexation reaction. Combined $X$-ray and NMR spectroscopic analyses indicate that coordination with two $\mathrm{Cr}(\mathrm{CO})_{3}$ groups at the convex side of DIN changes the structure of the ligand into a less bent and less favourable structure.
\end{abstract}

Until quite recently arene coordination reactions with tricarbonylchromium were known only for mono-, di- and polycyclic fused planar ligands. ${ }^{1}$ The complexation of bent di- or poly-arenes have received some attention in recent papers ${ }^{2}$ since the coordination with the inorganic group on either the convex or concave face of the arene is expected to occur with different rates giving rise to stereoisomers which in turn have different physical and chemical properties. We have reported, for example, that for 10-methyltribenzotriquinacene, MTBT, a bent triarene of $C_{3 \mathrm{v}}$ symmetry and rigid geometry, ${ }^{3}$ complexation of the convex side of a free benzene ring is favoured for steric reasons and that the stereoisomer with the tricarbonylchromium coordinated to the concave face $(s y n)$ is less stable than that complexed at the convex face (anti). The two isomers manifest different reactivity towards further complexation, and some specific ${ }^{1} \mathrm{H}$ and ${ }^{13} \mathrm{C}$ NMR spectroscopic characteristics have been correlated with different conformations adopted by the inorganic unit when bonded to the convex or concave side of the ligand. ${ }^{4}$

The linearly fused di-indan $4 b, 5,9 b, 10$-tetrahydroindeno[2,1a]indene, ${ }^{5}$ DIN, represents a different type of bent hydrocarbon and exhibits a $C_{2}$ symmetry axis.*

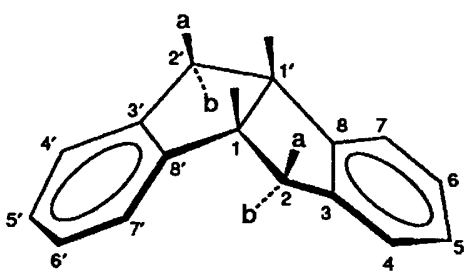

DIN

Unlike MTBT, the DIN molecule displays a certain degree of flexibility mainly due to possible limited torsions ( $c a .20-30^{\circ}$ ) about the bond joining the two methine carbon atoms $\mathrm{C}(1)$ and

* In our laboratories, the title di-indan has been conveniently synthesized in $80 \%$ yield from the corresponding 5,10-diketone (see ref. $5 a$ ) by reduction with $\mathrm{H}_{2} / \mathrm{Pd} / \mathrm{C}(10 \%)$ in ethanol (Parr hydrogenation apparatus; 5 bar, $25^{\circ} \mathrm{C}, 1 \mathrm{~d}$ ).

$\dagger$ For Part 1, see ref. 4.
$\mathrm{C}\left(1^{\prime}\right)$. In fact a clockwise or an anticlockwise rotation must take place primarily in order to avoid the eclipsed conformation about this bond, thus affording two energetically non equivalent conformers, viz. A and B.

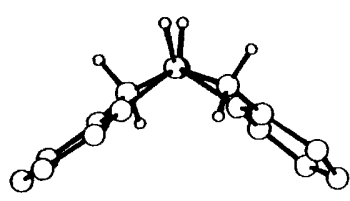

A

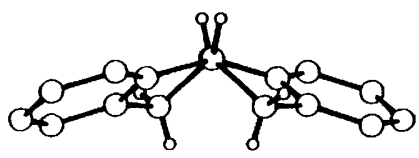

B
Moreover, the di-indan ligand contains methylene hydrogen atoms both of syn and anti type. Their presence will play an essential role in the insertion process of $\mathrm{Cr}(\mathrm{CO})_{3}$ in either of the conformers. The NMR spectroscopic and X-ray analyses could clarify in terms of geometrical considerations the relevant chemical results and physicochemical properties of the complexes described in this work.

\section{Results}

The tricarbonylchromium complexes 1-4 of DIN (Scheme 1) were prepared by boiling the hydrocarbon and $\operatorname{Cr}(\mathrm{CO})_{6}$ in a 90:10 v/v mixture of butyl ether-tetrahydrofuran (THF). Separation of the complexes was accomplished by medium pressure column chromatography on silica under argon, as described in the Experimental section.

By working with an excess of complexing agent and prolonged reaction times, we obtained $60 \%$ conversion of DIN into four different complexes (1-4) which were obtained in the yields indicated in Table 1 (run 1). They were isolated as bright, yellow, crystalline air-stable solids. On the basis of the NMR and mass spectra, and on X-ray measurements (see below), they have been identified as anti- $\mathrm{Cr}(\mathrm{CO})_{3}-\mathrm{DIN}, 1$, syn- $\mathrm{Cr}(\mathrm{CO})_{3^{-}}$ DIN, 2, anti,syn- $\left[\mathrm{Cr}(\mathrm{CO})_{3}\right]_{2}-\mathrm{DIN}, 3$, and anti, anti- $\left[\mathrm{Cr}(\mathrm{CO})_{3}\right]_{2}-$ DIN, 4. In order to drive the reaction towards monocomplexation, an excess of DIN over $\mathrm{Cr}(\mathrm{CO})_{6}$ and shorter reaction times were used in run 2 . In these experiments (conversion $c a .24 \%$ ) the relative yields of the isomers 1 and 2 

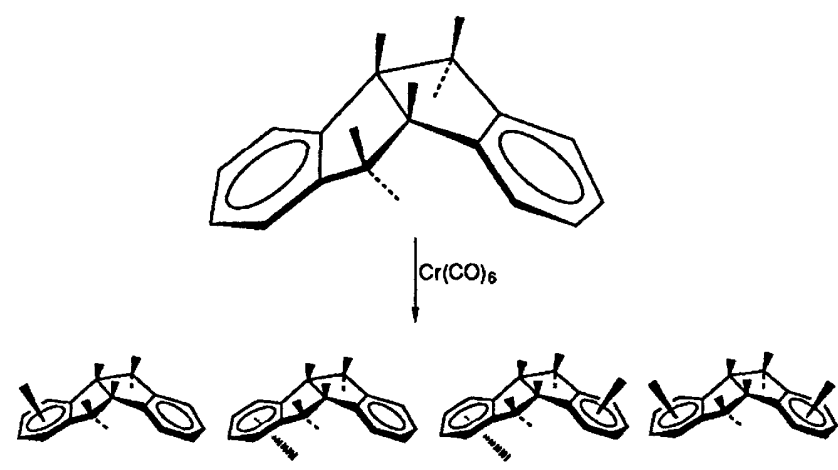

Scheme 1 Orientation of the $\mathrm{Cr}(\mathrm{CO})_{3}$ units in mono-and bis-complexed DINs

Table 1 Complexation products of free and $\mathrm{Cr}(\mathrm{CO})_{3}$-complexed DIN

\begin{tabular}{|c|c|c|c|c|c|c|c|c|}
\hline \multirow[b]{2}{*}{$\operatorname{Run}^{a}$} & \multirow{2}{*}{$\begin{array}{l}\text { Substrate/ } \\
\text { mol }\end{array}$} & \multirow{2}{*}{$\begin{array}{l}\mathrm{Cr}(\mathrm{CO})_{6}: \\
\text { substrate }\end{array}$} & \multirow[b]{2}{*}{$t / \mathrm{h}$} & \multirow{2}{*}{$\begin{array}{l}\text { Conversion } \\
(\%)^{b}\end{array}$} & \multicolumn{4}{|c|}{$\begin{array}{l}\text { Relative } \\
\text { yields }(\%)^{b}\end{array}$} \\
\hline & & & & & 1 & 2 & 3 & 4 \\
\hline 1 & DIN & $3: 1$ & 24 & 60 & 53 & 29 & & 5 \\
\hline 2 & DIN & $1: 1$ & 6 & 24 & 63 & 29 & & 2 \\
\hline 3 & 1 & $2: 1$ & 15 & $\simeq 1$ & & & & $c$ \\
\hline 4 & 2 & $2: 1$ & 15 & 17 & & & 100 & \\
\hline
\end{tabular}

${ }^{a}$ Solvent, butyl ether-THF, 90:10 v/v; $T 140{ }^{\circ} \mathrm{C} .{ }^{b}$ Conversions and yields were calculated from NMR spectra of the crude reaction mixture. The substrate was detected by NMR spectroscopy to the extent of the difference to $100 \%$. ${ }^{\circ}$ A $3 / 4$ ratio of $c a$. 2 was roughly estimated.

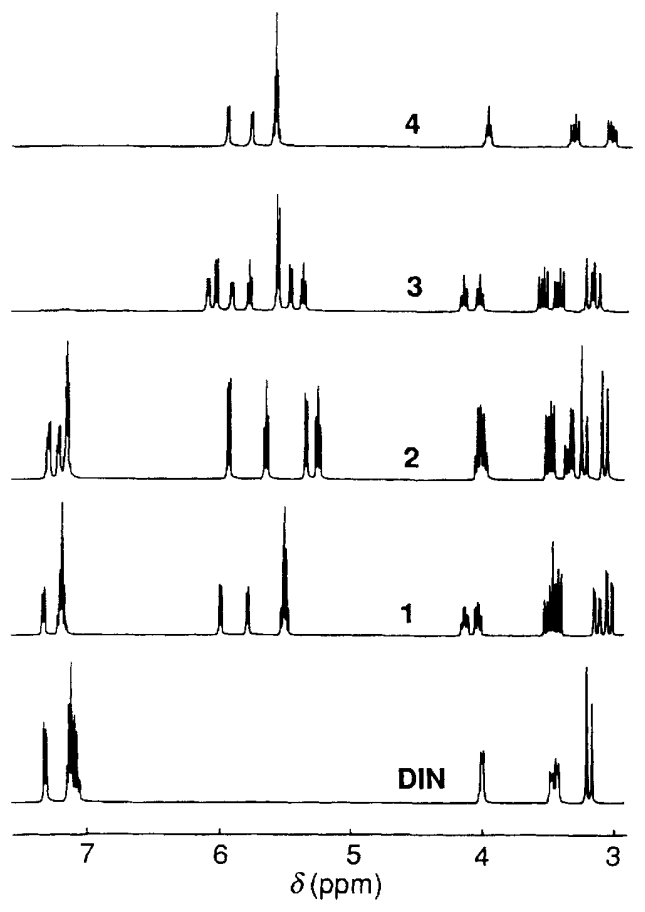

Fig. $1{ }^{1} \mathrm{H}$ NMR spectra of the free and $\mathrm{Cr}(\mathrm{CO})_{3}$-complexed DINs. Solvent, $\left[{ }^{2} \mathrm{H}_{6}\right.$ ]acetone; $T 289 \mathrm{~K} ; v_{0} 400.13 \mathrm{MHz} ; \delta$ in $\mathrm{ppm}$ from internal $\mathrm{Me}_{4} \mathrm{Si}$

were only slightly changed, and the formation of the biscomplexes 3 and 4 was reduced to a half.

Reaction of 2 with $\mathrm{Cr}(\mathrm{CO})_{6}$ for $15 \mathrm{~h}$ (run 4 ) gave a $17 \%$ yield of the 3 as the only reaction product; on the other hand, complex 1 was found to be very poorly reactive under the same conditions ( $\mathrm{ca} .1 \%$ conversion), and an approximately $2: 1$ mixture of 3 and 4 was obtained (run 3).
Table $2 \quad{ }^{1} \mathrm{H}$ NMR parameters ${ }^{a}$ for DIN and complexes 1-4

\begin{tabular}{llllll}
\hline & \multicolumn{5}{l}{ Chemical shifts $^{b}\left(\delta_{i}\right)$} \\
\cline { 2 - 6 } H $(i)$ & DIN & $\mathbf{1}$ & $\mathbf{2}$ & $\mathbf{3}$ & $\mathbf{4}$ \\
\hline $1^{\prime}$ & 4.004 & 4.030 & 4.031 & 4.136 & 3.954 \\
$1^{\prime}$ & 4.004 & 4.127 & 3.986 & 4.018 & 3.954 \\
2a & 3.451 & 3.490 & 3.336 & 3.417 & 3.301 \\
$2^{\prime} \mathrm{a}$ & 3.451 & 3.428 & 3.483 & 3.537 & 3.020 \\
2b & 3.187 & 3.127 & 3.226 & 3.190 & 3.301 \\
$2^{\prime} \mathrm{b}$ & 3.187 & 3.033 & 3.071 & 3.130 & 3.020 \\
4 & 7.121 & 7.192 & 7.214 & 5.906 & 5.753 \\
5 & 7.073 & 7.168 & 7.143 & 5.553 & 5.563 \\
6 & 7.127 & 7.201 & 7.150 & 5.554 & 5.577 \\
7 & 7.318 & 7.329 & 7.293 & 6.086 & 5.936 \\
$4^{\prime}$ & 7.121 & 5.782 & 5.340 & 5.456 & 5.753 \\
$5^{\prime}$ & 7.073 & 5.492 & 5.643 & 5.769 & 5.563 \\
$6^{\prime}$ & 7.127 & 5.511 & 5.247 & 5.362 & 5.577 \\
$7^{\prime}$ & 7.318 & 5.989 & 5.929 & 6.021 & 5.936 \\
\hline
\end{tabular}

${ }^{a} T 298 \mathrm{~K}$, solvent $\left[{ }^{2} \mathrm{H}_{6}\right]$ acetone, internal standard $\mathrm{Me}_{4} \mathrm{Si}$. For proton labelling, see Scheme 1. ${ }^{b}$ The uncertainties are $\leq 0.001 \mathrm{ppm}$.

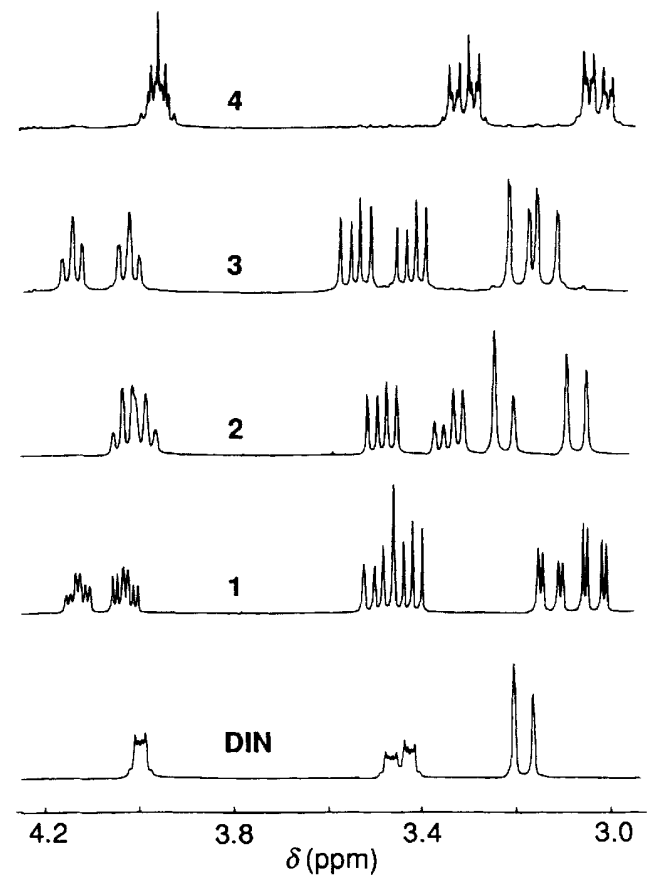

Fig. 2 High field portion of the ${ }^{1} H$ NMR spectra of DIN and the complexes 1-4. For the experimental conditions, see Fig. 1

NMR Spectroscopic Measurements.-The ${ }^{1} \mathrm{H}$ (see Fig. 1) and ${ }^{13} \mathrm{C}$ NMR spectra of 1-4 have been used for identification. The proton assignments given in Table 2 were performed by selective decoupling and $\left\{{ }^{1} \mathrm{H}\right\}-{ }^{1} \mathrm{H}$ NOE measurements. The spectra of the aliphatic moiety of the molecules are shown in Fig. 2, and selected ${ }^{3} J_{\mathrm{H}, \mathrm{H}}$ coupling constant values are listed in Table 3. The ${ }^{13} \mathrm{C}$ NMR resonances were attributed to the corresponding nuclei by selective proton decoupling experiments and partially relaxed spectra, and they are reported in Table 4 together with the corresponding ${ }^{1} J_{\mathrm{C}-\mathrm{H}}$ values.

The ligand. The ${ }^{1} \mathrm{H}$ spectrum of DIN exhibits an ABCD pattern due to the aromatic protons in the range $\delta 7.4-7.0$; the multiplet centred at $\delta 4.004$ is attributed to the methine $\mathrm{H}(1)$ and $\mathrm{H}\left(1^{\prime}\right)$ protons, and the signals due to the methylene protons appear at $\delta 3.451$ and 3.187 . The lower field resonance exhibits a $7.95 \mathrm{~Hz}$ coupling constant with the adjacent methine proton, this coupling being reduced to $1.79 \mathrm{~Hz}$ for the high field signal. On the basis of geometrical considerations on the aliphatic part of the molecule, we assign the lower field resonance to the 
Table 3 Selected ${ }^{3} J\left(\mathrm{H}_{i}, \mathrm{H}_{j}\right)$ values for DIN and complexes $1-\mathbf{4}^{a}$

\begin{tabular}{llllllll}
\hline \multicolumn{7}{c}{ Compound } & \multicolumn{1}{l}{$\mathrm{H}_{i} \mathrm{H}_{j}$ nuclei } \\
\cline { 2 - 8 } & $\mathrm{H}(1), \mathrm{H}(2 \mathrm{a})$ & $\mathrm{H}(1), \mathrm{H}(2 \mathrm{~b})$ & $\mathrm{H}\left(1^{\prime}\right), \mathrm{H}\left(2^{\prime} \mathrm{a}\right)$ & $\mathrm{H}\left(1^{\prime}\right), \mathrm{H}\left(2^{\prime} \mathrm{b}\right)$ & $\mathrm{H}(1), \mathrm{H}\left(1^{\prime}\right)$ & $\mathrm{H}(2 \mathrm{a}), \mathrm{H}(2 \mathrm{~b})$ & $\mathrm{H}\left(2^{\prime} \mathrm{a}\right), \mathrm{H}\left(2^{\prime} \mathrm{b}\right)$ \\
\hline \multirow{2}{*}{ DIN } & $7.95(0.03)$ & $1.79(0.03)$ & $7.95(0.03)$ & $1.79(0.03)$ & $7.46(0.04)$ & $-16.20(0.02)$ & $-16.20(0.02)$ \\
$\mathbf{1}$ & $9.23(0.01)$ & $3.93(0.01)$ & $8.85(0.01)$ & $3.90(0.01)$ & $8.00(0.01)$ & $-16.63(0.01)$ & $-16.45(0.01)$ \\
$\mathbf{2}$ & $8.43(0.06)$ & $1.29(0.06)$ & $8.85(0.09)$ & $1.97(0.06)$ & $8.31(0.06)$ & $-16.44(0.06)$ & $-16.54(0.06)$ \\
$\mathbf{3}$ & $8.67(0.02)$ & $1.53(0.02)$ & $9.39(0.02)$ & $1.63(0.02)$ & $8.11(0.02)$ & $-16.76(0.02)$ & $-16.97(0.02)$ \\
$\mathbf{4}$ & $9.31(0.02)$ & $8.08(0.01)$ & $9.31(0.02)$ & $8.08(0.01)$ & $8.25(0.02)$ & $-16.32(0.01)$ & $-16.32(0.01)$ \\
\hline
\end{tabular}

${ }^{a}$ Values given in $\mathrm{Hz}$ (standard errors in parentheses). For experimental conditions, see Table 2. A full list of the $J_{i, j}$ coupling constant values is deposited as supplementary material.

Table $4{ }^{13} \mathrm{C}$ NMR chemical shifts, ${ }^{a} \delta$ (ppm), and ${ }^{1} J_{\mathrm{CH}} / \mathrm{Hz}$ (in parentheses) for DIN and complexes 1-4

\begin{tabular}{|c|c|c|c|c|c|}
\hline$C(i)$ & DIN & 1 & 2 & 3 & 4 \\
\hline \multirow[t]{2}{*}{1} & 49.50 & 39.48 & 48.08 & 47.89 & 50.01 \\
\hline & (130) & $\begin{array}{l}(130) \\
3008\end{array}$ & $(137)$ & $\begin{array}{l}(140) \\
3885\end{array}$ & $\begin{array}{l}(142) \\
3915\end{array}$ \\
\hline 2 & $\begin{array}{l}39.48 \\
(130)\end{array}$ & $\begin{array}{l}39.98 \\
(132)\end{array}$ & $\begin{array}{c}39.37 \\
(130 ; 135)\end{array}$ & $\begin{array}{l}38.85 \\
(134)\end{array}$ & $\begin{array}{c}39.15 \\
(129 ; 139)\end{array}$ \\
\hline \multirow[t]{2}{*}{3} & 143.34 & 146.36 & 142.28 & 120.13 & 117.76 \\
\hline & $(-)$ & $(-)$ & $(-)$ & $(-)$ & $(-)$ \\
\hline 4 & $\begin{array}{l}125.13 \\
(158)\end{array}$ & $\begin{array}{l}125.55 \\
(159)\end{array}$ & $\begin{array}{l}126.33 \\
(158)\end{array}$ & $\begin{array}{l}93.51 \\
(175)\end{array}$ & $\begin{array}{l}92.16 \\
(175)\end{array}$ \\
\hline \multirow[t]{2}{*}{5} & 127.35 & 128.11 & 127.88 & 94.63 & 94.21 \\
\hline & $(160)$ & $(160)$ & (159) & (174) & (176) \\
\hline 6 & $\begin{array}{l}127.60 \\
(159)\end{array}$ & $\begin{array}{l}127.91 \\
(160)\end{array}$ & $\begin{array}{l}127.38 \\
(159)\end{array}$ & $\begin{array}{l}93.87 \\
(175)\end{array}$ & $\begin{array}{l}94.26 \\
(175)\end{array}$ \\
\hline 7 & $\begin{array}{l}124.30 \\
(157)\end{array}$ & $\begin{array}{l}125.33 \\
(158)\end{array}$ & $\begin{array}{l}124.81 \\
(156)\end{array}$ & $\begin{array}{l}92.75 \\
(173)\end{array}$ & $\begin{array}{c}92.24 \\
(176)\end{array}$ \\
\hline 8 & $\begin{array}{l}147.46 \\
(-)\end{array}$ & $\begin{array}{l}142.57 \\
(-)\end{array}$ & $\begin{array}{l}146.62 \\
(-)\end{array}$ & $\begin{array}{l}116.01 \\
(-)\end{array}$ & $\begin{array}{l}115.09 \\
(-)\end{array}$ \\
\hline $\mathrm{C} \equiv \mathrm{O}$ & - & - & - & 235.16 & 234.70 \\
\hline $1^{\prime}$ & $\begin{array}{l}49.50 \\
(130)\end{array}$ & $\begin{array}{l}49.88 \\
(138)\end{array}$ & $\begin{array}{c}48.04 \\
(137)\end{array}$ & $\begin{array}{l}47.89 \\
(140)\end{array}$ & $\begin{array}{c}50.01 \\
(142)\end{array}$ \\
\hline $2^{\prime}$ & $\begin{array}{l}39.48 \\
(130)\end{array}$ & $\begin{array}{l}39.70 \\
(133)\end{array}$ & $\begin{array}{c}38.60 \\
(130 ; 132)\end{array}$ & $\begin{array}{c}38.47 \\
(135 ; 132)\end{array}$ & $\begin{array}{c}39.15 \\
(129 ; 139)\end{array}$ \\
\hline $3^{\prime}$ & $\begin{array}{l}143.34 \\
(-)\end{array}$ & $\begin{array}{l}120.14 \\
(-)\end{array}$ & $\begin{array}{l}118.46 \\
(-)\end{array}$ & $\begin{array}{l}117.58 \\
(-)\end{array}$ & $\begin{array}{l}117.76 \\
(-)\end{array}$ \\
\hline $4^{\prime}$ & $\begin{array}{l}125.13 \\
(158)\end{array}$ & $\begin{array}{l}92.63 \\
(176)\end{array}$ & $\begin{array}{l}86.84 \\
(174)\end{array}$ & $\begin{array}{l}87.20 \\
(173)\end{array}$ & $\begin{array}{l}92.16 \\
(175)\end{array}$ \\
\hline $5^{\prime}$ & $\begin{array}{l}127.35 \\
(160)\end{array}$ & $\begin{array}{l}94.38 \\
(175)\end{array}$ & $\begin{array}{l}97.35 \\
(173)\end{array}$ & $\begin{array}{l}98.03 \\
(174)\end{array}$ & $\begin{array}{c}94.21 \\
(175)\end{array}$ \\
\hline $6^{\prime}$ & $\begin{array}{l}127.60 \\
(159)\end{array}$ & $\begin{array}{l}94.00 \\
(175)\end{array}$ & $\begin{array}{l}89.73 \\
(175)\end{array}$ & $\begin{array}{l}90.20 \\
(176)\end{array}$ & $\begin{array}{l}94.26 \\
(175)\end{array}$ \\
\hline $7^{\prime}$ & $\begin{array}{l}124.30 \\
(157)\end{array}$ & $\begin{array}{l}92.65 \\
(176)\end{array}$ & $\begin{array}{l}93.97 \\
(172)\end{array}$ & $\begin{array}{l}94.31 \\
(173)\end{array}$ & $\begin{array}{l}92.24 \\
(175)\end{array}$ \\
\hline $8^{\prime}$ & $\begin{array}{l}147.46 \\
(-)\end{array}$ & $\begin{array}{l}116.48 \\
(-)\end{array}$ & $\begin{array}{l}117.13 \\
(-)\end{array}$ & $\begin{array}{l}116.28 \\
(-)\end{array}$ & $\begin{array}{l}115.09 \\
(-)\end{array}$ \\
\hline$C^{\prime} \equiv O$ & - & 235.05 & 234.09 & 234.16 & 234.70 \\
\hline
\end{tabular}

${ }^{a} T 298 \mathrm{~K}$, solvent $\left[{ }^{2} \mathrm{H}_{6}\right]$ acetone, internal standard $\mathrm{Me}_{4} \mathrm{Si}$. For carbon labelling, see Scheme $1 .^{b}$ The uncertainties are $\leq 0.01 \mathrm{ppm}$.

methylene hydrogens located in the convex side of the molecule, i.e. to the anti-H(2a) and the higher field one to the $s y n-\mathrm{H}(2 \mathrm{~b})$ protons. The assignments were confirmed by NOE measurements, which also allow us to attribute the lowest field resonance system occurring at $\delta 7.318$ to $\mathrm{H}(7)$, i.e. to the protons at the ortho position with respect to the methine position. This is a common feature for the ${ }^{1} \mathrm{H}$ NMR spectra of all the DIN derivatives reported here.

Mono-complexes 1 and 2. By complexation of one benzene ring with $\mathrm{Cr}(\mathrm{CO})_{3}$ to the convex or to the concave side of DIN the molecular symmetry of the ligand is removed. The effect of the complexation on the chemical shifts is sufficient to make all the resonances of both the aromatic and the aliphatic moieties of the mono-complexes clearly distinguishable (see Fig. 1). In particular, the ${ }^{1} \mathrm{H}$ NMR spectra of 1 and 2 consist of an ABCD system between $\delta 7.4$ and 7.1 attributed to the protons of the uncomplexed ring on the basis of the chemical shift values. Another ABCD pattern belonging to the protons of the complexed ring is found between $\delta 6.0$ and 5.4 for 1 and between $\delta 6.0$ and 5.2 for 2 . The signals due to the aliphatic nuclei appear as two distinct sets, as expected, and the assignments were accomplished by NOE measurements. The number of signals in the proton decoupled ${ }^{13} \mathrm{C}$ NMR spectra is consistent with the absence of molecular symmetry in the two complexes. The most important difference between the two spectra is the value of the difference of the chemical shift, $\Delta \delta_{{ }^{13} \mathrm{c}}$, found for the two quaternary carbon atoms belonging to the complexed ring, viz. $3.76 \mathrm{ppm}$ for 1 and $1.33 \mathrm{ppm}$ for 2 , together with the more pronounced spread of the resonances of the tertiary carbon nuclei of the complexed ring, viz. $1.75 \mathrm{ppm}$ for 1 and $10.51 \mathrm{ppm}$ for 2 . In addition, the $\mathrm{C} \equiv \mathrm{O}$ resonance of $\mathbf{1}(\delta 235.06)$ appears at a significant lower field than that of 2 ( $\delta$ 234.09). This has been already found for the $\operatorname{Cr}(\mathrm{CO})_{3}$ complexes of MTBT. ${ }^{4}$

Bis-complexes 3 and 4 . The ${ }^{1} \mathrm{H}$ NMR spectrum of the firsteluted bis-complexed DIN, 3, indicates the absence of molecular symmetry. In fact, two different ABCD systems were found in the range $\delta 6.1-5.3$, together with two sets of resonances due to the aliphatic moiety. In addition, all the 16 carbon nuclei resonances of the organic moiety are found in the ${ }^{13} \mathrm{C}$ spectrum, and two different signals for the $\mathrm{C} \equiv \mathrm{O}$ carbons are also observed at $\delta 235.16$ and 234.16. The results clearly indicate that the two $\mathrm{Cr}(\mathrm{CO})_{3}$ units are coordinated one to the convex and the other to the concave side of the ligand, as confirmed by the X-ray structure (see below). The proton and carbon NMR spectra of $\mathbf{4}$, on the contrary, show the presence of two equivalent $\mathrm{Cr}(\mathrm{CO})_{3}$ coordinated benzene rings, as indicated by the single $\mathrm{ABCD}$ pattern for the aromatic protons occurring between $\delta 6.0$ and 5.5 , together with only one methine resonance pattern centred at $\delta 3.954$ and only one set of resonances due to the methylene protons at $\delta 3.301$ and 3.020 for the anti and syn hydrogen atoms. In addition to the equivalence of the aromatic, methine and methylene carbon atoms, only one signal for the $\mathrm{C} \equiv \mathrm{O}$ carbon atoms is found in the ${ }^{13} \mathrm{C}$ spectrum at $\delta 234.70$.

$X$-Ray Measurements.-Suitable crystals for diffractometric analysis were obtained by slow evaporation under an inert atmosphere of concentrated solutions of 3 and 4 in a $1: 1: 1$ mixture of acetone, methanol and methylene dichloride. No single crystals could be obtained from solutions of 2 in the above mentioned and other similar solvent mixtures. Even though good crystals were obtained for $\mathbf{1}$, the structure could not be resolved owing to an exceedingly high crystallographic disorder.

The results of the $\mathrm{X}$-ray analysis for the two bis-complexes are shown in Figs. 3 and 4. In complex 3 one of the two $\operatorname{Cr}(\mathrm{CO})_{3}$ units is bonded to the convex side of the organic ligand and the other to the concave one. The two metal groups in $\mathbf{4}$ are both bonded in equivalent positions to the concave side of DIN in the anti,anti positions. Crystal data and details of the intensity data collected for complexes $\mathbf{3}$ and $\mathbf{4}$ are reported in Table 5. 


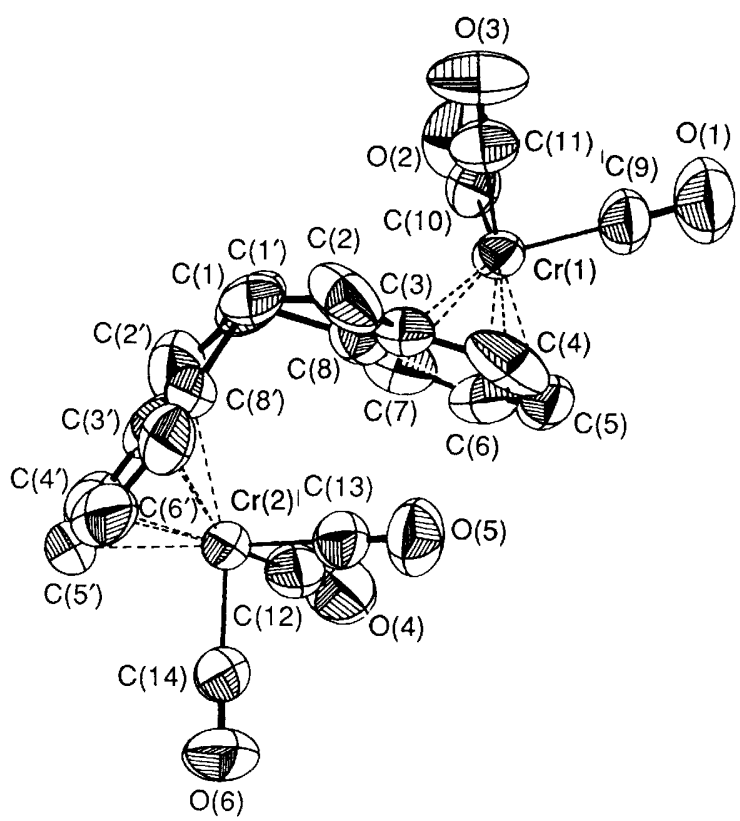

Fig. 3 Projection of the molecule of 3 as viewed along the $\mathrm{C}(1)-\mathrm{C}\left(1^{\prime}\right)$ bond

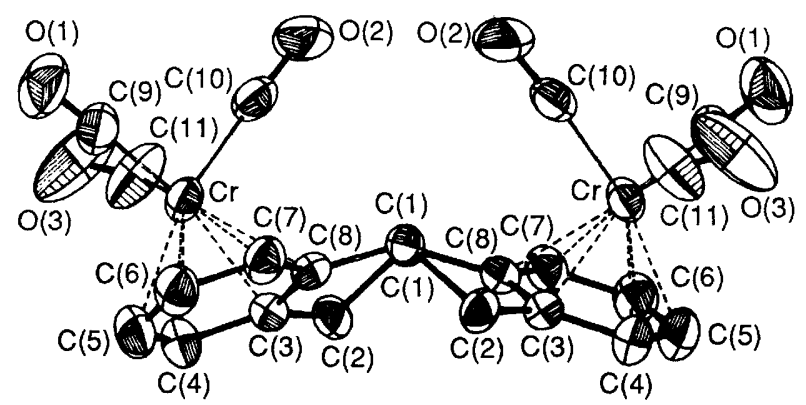

Fig. 4 Projection of the molecule of 4 as viewed along the $\mathrm{C}(1)-\mathrm{C}\left(1^{\prime}\right)$ bond

Table 5 Summary of crystal data and intensity collection for complexes 3 and $\mathbf{4}$

\begin{tabular}{|c|c|c|}
\hline Compound & 3 & 4 \\
\hline $\begin{array}{l}\text { Formula } \\
M\end{array}$ & $\begin{array}{l}\mathrm{C}_{22} \mathrm{H}_{14} \mathrm{Cr}_{2} \mathrm{O}_{6} \\
478.34\end{array}$ & $\begin{array}{l}\mathrm{C}_{22} \mathrm{H}_{14} \mathrm{Cr}_{2} \mathrm{O}_{6} \\
478.34\end{array}$ \\
\hline$a / \AA$ & $16.374(9)$ & $18.677(9)$ \\
\hline$b / \AA$ & $11.002(6)$ & $7.087(5)$ \\
\hline$c / \AA$ & $11.109(6)$ & $15.088(8)$ \\
\hline$\beta /^{\circ}$ & $101.0(2)$ & $91.1(1)$ \\
\hline$V / \AA^{3}$ & 1964.5 & 1996.7 \\
\hline$Z$ & 4 & 4 \\
\hline$D_{\mathrm{c}} / \mathrm{g} \mathrm{cm}^{-3}$ & 1.62 & 1.59 \\
\hline Space group & $P 2_{1} / a$ & $C 2 / c$ \\
\hline Crystal dimensions $/ \mathrm{mm}$ & $0.2 \times 0.3 \times 0.2$ & $0.3 \times 0.15 \times 0.15$ \\
\hline$T / \mathrm{K}$ & 298 & 298 \\
\hline Radiation & \multicolumn{2}{|c|}{$\begin{array}{l}\text { graphite-monochromated } \\
\operatorname{Mo}-K \alpha(\lambda=0.7107 \AA)\end{array}$} \\
\hline$\mu / \mathrm{cm}^{-1}$ & 12.78 & 12.57 \\
\hline Take-off angle $/^{\circ}$ & 3.0 & 3.0 \\
\hline Scan speed $/{ }^{\circ} \min ^{-1}$ & \multicolumn{2}{|c|}{2.0 in the $\theta$ mode } \\
\hline $2 \theta$ range $/^{\circ}$ & \multicolumn{2}{|c|}{$3.0 \leq 2 \theta \leq 45$} \\
\hline Unique data $\left[F_{0}^{2}>2 \sigma\left(F_{0}^{2}\right)\right]$ & 4625 & 2162 \\
\hline$R\left(\right.$ on $\left.F_{0}\right)$ & 0.065 & 0.052 \\
\hline
\end{tabular}

\section{Discussion}

The results summarized in Table 1 indicate that the complexation with one $\mathrm{Cr}(\mathrm{CO})_{3}$ group at the convex side of the ligand is favoured as compared to syn complexation, and an anti/syn preference of $c a .2$ can be estimated from the product ratios $1: 2$ in both the runs 1 and 2 . This result parallels the trend reported ${ }^{4}$ for the MTBT ligand, and the difference in reactivity between the convex and the concave side is likely to be ascribed to steric reasons. Runs 1 and 2 show also that the formation of the bis-complex 3 is favoured with respect to that of the complex 4 , and the result is confirmed by the results of runs 3 and 4 . In fact, by reacting 1 with $\mathrm{Cr}(\mathrm{CO})_{6}$, the bis-complexes were hardly detectable in contrast with the higher reactivity of complex 2 which produces only the species 3 . Therefore, the reactivity towards the second metallation depends on the syn or anti coordination of the adjacent benzene ring.

$X$-Ray Data.-The di-indan ligand of the complexes described here is a bent hydrocarbon with $C_{2}$ symmetry, and contains two stereoisomeric centres on $\mathrm{C}(1)$ and $\mathrm{C}\left(1^{\prime}\right)$ having the same configuration. As a first approximation this molecule can be considered quite rigid except for a limited torsional freedom about the $\mathrm{C}(1)-\mathrm{C}\left(1^{\prime}\right)$ bond of the two indan moieties; a rotation is required, however, in order to avoid an 'eclipsed' conformation about this bond and the unfavoured planar conformation of the two five membered rings.

Though not structurally determined two possible conformations are predictable. As discussed above, an anticlockwise rotation about this bond ( $c a .20-30^{\circ}$ ) affords the conformer $\mathbf{A}$ while a clockwise rotation ( $\mathrm{ca}$. -20 to $30^{\circ}$ ) gives the conformer $\mathbf{B}$ (the sense of rotation obviously depends on the enantiomer chosen). Due to the enantiomorphic character of the ligand, these conformers are geometrically and energetically non equivalent.

The relevant features expected for $\mathbf{A}$ are: $(a)$ the five membered rings are puckered towards the concave side of the molecule thus increasing the bent shape of the whole ligand; (b) the orientation of the methine hydrogen atoms $\mathrm{H}(1)$ and $\mathrm{H}\left(1^{\prime}\right)$ with respect to the adjacent methylene hydrogen atoms $\mathrm{H}(2 \mathrm{a})$ and $\mathrm{H}(2 \mathrm{~b})$ and $\mathrm{H}\left(2^{\prime} \mathrm{a}\right)$ and $\mathrm{H}\left(2^{\prime} \mathrm{b}\right)$ are defined by torsion angles $\sigma_{1}=\mathrm{H}(1)-\mathrm{C}(1)-\mathrm{C}(2)-\mathrm{H}(2 \mathrm{a})=+20-30^{\circ}$ and $\sigma_{2}=$ $\mathrm{H}(1)-\mathrm{C}(1)-\mathrm{C}(2)-\mathrm{H}(2 \mathrm{~b})=-90$ to $100^{\circ}$ [the same holds for $\sigma_{1}^{\prime}=\mathrm{H}\left(1^{\prime}\right)-\mathrm{C}\left(1^{\prime}\right)-\mathrm{C}\left(2^{\prime}\right)-\mathrm{H}\left(2^{\prime} \mathrm{a}\right)$ and $\sigma_{2}^{\prime}=\mathrm{H}\left(1^{\prime}\right)-\mathrm{C}\left(1^{\prime}\right)-$ $\mathrm{C}\left(2^{\prime}\right)-\mathrm{H}\left(2^{\prime} \mathrm{b}\right)$, respectively]; (c) the two methylene syn-hydrogen atoms $\mathrm{H}(2 \mathrm{~b})$ and $\mathrm{H}\left(2^{\prime} \mathrm{b}\right)$ move further away from each other and from the central normal to the adjacent benzene ring; $(d)$ the methylene anti-hydrogen atoms $\mathrm{H}(2 \mathrm{a})$ and $\mathrm{H}\left(2^{\prime} \mathrm{a}\right)$ and the methine hydrogen atoms $\mathrm{H}(1)$ and $\mathrm{H}\left(1^{\prime}\right)$ get closer to each other.

One can easily realize that insertion of a $s y n-\mathrm{Cr}(\mathrm{CO})_{3}$ group is only possible under condition $(c)$, and among the possible conformations of the $\mathrm{Cr}(\mathrm{CO})_{3}$ tripod the more favoured is the exo one. ${ }^{6}$ All these features have been found in the structure of the syn-anti bis- $\left[\mathrm{Cr}(\mathrm{CO})_{3}\right]_{2}$ di-indan complex 3 (see Fig. 3 and Table 6).

The $s y n-\mathrm{Cr}(\mathrm{CO})_{3}$ tripod is rotated $c a .10^{\circ}$ about the chromium-arene bond from an idealized 'staggered' conformation giving rise to distances from the $C(13)-O(5)$ and $\mathrm{C}(12)-\mathrm{O}(4)$ bond middle points to $\mathrm{H}(2 \mathrm{~b})$ and $\mathrm{H}\left(2^{\prime} \mathrm{b}\right)$ of $c a .2 .65$ and $3.00 \AA$, respectively. This recurring feature is present in almost all these and similar complexes and it does not seem to be imposed by steric requirements; on the contrary, it is probably due to a stabilizing interaction between $\mathrm{H}(2 \mathrm{~b})$ and the nearby carbonyl group, as already discussed in a previous paper. ${ }^{4}$ The chromium atom lies almost exactly on the central normal to its complexed benzene ring. The NMR spectra (vide infra) are in agreement with feature $(b)$. Feature $(d)$, imposed by the syn complexation, is completely unfavourable for either a staggered endo or exo conformation of an anti- $\mathrm{Cr}(\mathrm{CO})_{3}$ tripod complexed on the other benzene ring. As a consequence, the only allowed conformation of this group must be the 'eclipsed' one, as actually found in the structure where again one $\mathrm{C} \equiv \mathrm{O}$ 
Table 6 Some relevant geometrical parameters for the complex 3

\begin{tabular}{|c|c|c|c|}
\hline \multicolumn{4}{|c|}{ Bond lengths and intramolecular interatomic distances $/ \AA$} \\
\hline $\mathrm{Cr}(1)-\mathrm{C}(3)$ & $2.224(6)$ & $\mathrm{Cr}(2)-\mathrm{C}\left(3^{\prime}\right)$ & $2.239(7)$ \\
\hline $\mathrm{Cr}(1)-\mathrm{C}(4)$ & $2.161(6)$ & $\mathrm{Cr}(2)-\mathrm{C}\left(4^{\prime}\right)$ & $2.209(9)$ \\
\hline $\mathrm{Cr}(1)-\mathrm{C}(5)$ & $2.158(6)$ & $\mathrm{Cr}(2)-\mathrm{C}\left(5^{\prime}\right)$ & $2.179(9)$ \\
\hline $\mathrm{Cr}(1)-\mathrm{C}(6)$ & $2.218(6)$ & $\mathrm{Cr}(2)-\mathrm{C}\left(6^{\prime}\right)$ & $2.179(8)$ \\
\hline $\mathrm{Cr}(1)-\mathrm{C}(7)$ & $2.279(7)$ & $\operatorname{Cr}(2)-C\left(7^{\prime}\right)$ & $2.209(8)$ \\
\hline $\mathrm{Cr}(1)-\mathrm{C}(8)$ & $2.228(7)$ & $\mathrm{Cr}(2)-\mathrm{C}\left(8^{\prime}\right)$ & $2.239(8)$ \\
\hline $\mathrm{Cr}(1)-\mathrm{C}(9)$ & $1.81(1)$ & $\mathrm{Cr}(2)-\mathrm{C}(12)$ & $1.85(1)$ \\
\hline $\mathrm{Cr}(1)-\mathrm{C}(10)$ & $1.82(1)$ & $\mathrm{Cr}(2)-\mathrm{C}(13)$ & $1.84(1)$ \\
\hline $\mathrm{Cr}(1)-\mathrm{C}(11)$ & $1.84(1)$ & $\mathrm{Cr}(2)-\mathrm{C}(14)$ & $1.85(1)$ \\
\hline $\mathrm{O}(1)-\mathrm{C}(9)$ & $1.15(1)$ & $\mathrm{O}(4)-\mathrm{C}(12)$ & $1.16(1)$ \\
\hline $\mathrm{O}(2)-\mathrm{C}(10)$ & $1.19(1)$ & $\mathrm{O}(5)-\mathrm{C}(13)$ & $1.16(1)$ \\
\hline $\mathrm{O}(3)-\mathrm{C}(11)$ & $1.15(1)$ & $\mathrm{O}(6)-\mathrm{C}(14)$ & $1.15(1)$ \\
\hline $\mathrm{M}(3) \cdots \mathrm{H}(1 \mathrm{a})^{a}$ & 2.83 & $M(4) \ldots H(2 b)$ & 3.00 \\
\hline $\mathrm{M}(5) \ldots \mathrm{H}(2 \mathrm{~b})^{a}$ & 2.65 & & \\
\hline
\end{tabular}

Bond angles/ $/ 0$

$\begin{array}{lrlr}\mathrm{C}(10)-\mathrm{Cr}(1)-\mathrm{C}(11) & 90.4(5) & \mathrm{C}(13)-\mathrm{Cr}(2)-\mathrm{C}(14) & 88.9(5) \\ \mathrm{C}(9)-\mathrm{Cr}(1)-\mathrm{C}(11) & 88.1(5) & \mathrm{C}(13)-\mathrm{Cr}(2)-\mathrm{C}(12) & 87.3(5) \\ \mathrm{C}(9)-\mathrm{Cr}(1)-\mathrm{C}(10) & 88.7(5) & \mathrm{C}(12)-\mathrm{Cr}(2)-\mathrm{C}(14) & 89.3(5) \\ \mathrm{Cr}(1)-\mathrm{C}(9)-\mathrm{O}(1) & 180.0(9) & \mathrm{Cr}(2)-\mathrm{C}(12)-\mathrm{O}(4) & 176.1(9) \\ \mathrm{Cr}(1)-\mathrm{C}(10)-\mathrm{O}(2) & 178.4(9) & \mathrm{Cr}(2)-\mathrm{C}(13)-\mathrm{O}(5) & 178.6(9) \\ \mathrm{Cr}(1)-\mathrm{C}(11)-\mathrm{O}(3) & 178.0(9) & \mathrm{Cr}(2)-\mathrm{C}(14)-\mathrm{O}(6) & 180.0(9)\end{array}$

Torsion angles $/^{\circ}$

$\begin{array}{lr}\mathrm{C}\left(5^{\prime}\right)-\mathrm{P}(2)-\mathrm{Cr}(2)-\mathrm{C}(14)^{b} & 18.7 \\ \mathrm{C}\left(3^{\prime}\right)-\mathrm{P}(2)-\mathrm{Cr}(2)-\mathrm{C}(12)^{b} & 18.7 \\ \mathrm{C}\left(7^{\prime}\right)-\mathrm{P}(2)-\mathrm{Cr}(2)-\mathrm{C}(13)^{b} & 18.3 \\ \mathrm{H}(1)-\mathrm{C}(1)-\mathrm{C}(2)-\mathrm{H}(2) 1 & 19.2 \\ \mathrm{H}(1)-\mathrm{C}(1)-\mathrm{C}(2)-\mathrm{H}(2) 2 & -100.6 \\ \mathrm{C}(5)-\mathrm{P}(1)-\mathrm{Cr}(1)-\mathrm{C}(9)^{b} & -0.4 \\ \mathrm{C}(7)-\mathrm{P}(1)-\mathrm{Cr}(1)-\mathrm{C}(10)^{b} & 1.1 \\ \mathrm{C}(3)-\mathrm{P}(1)-\mathrm{Cr}(1)-\mathrm{C}(11)^{b} & 0.5 \\ \mathrm{H}\left(1^{\prime}\right)-\mathrm{C}\left(1^{\prime}\right)-\mathrm{C}\left(2^{\prime}\right)-\mathrm{H}\left(1^{\prime} \mathrm{b}\right) & 17.6 \\ \mathrm{H}\left(1^{\prime}\right)-\mathrm{C}\left(1^{\prime}\right)-\mathrm{C}\left(2^{\prime}\right)-\mathrm{H}\left(2^{\prime} b\right) & -103.7\end{array}$

${ }^{a} \mathrm{M}(\mathrm{n})$ indicates the location of the middle point of the corresponding $\mathrm{C} \equiv \mathrm{O}(\mathrm{n})$ group. ${ }^{b}$ Idealised torsion angles about the normal to the complexed benzene rings passing through the $\mathrm{Cr}$ atoms; $\mathrm{P}(1)$ and $\mathrm{P}(2)$ indicate the location of the centre of the benzene rings.

Table 7 Some relevant geometrical parameters for the complex 4

\begin{tabular}{llll}
\hline Bond lengths and intramolecular interatomic distances $/ \AA$ & \\
$\mathrm{Cr}-\mathrm{C}(3)$ & $2.213(3)$ & $\mathrm{Cr}-\mathrm{C}(11)$ & $1.828(6)$ \\
$\mathrm{Cr}-\mathrm{C}(4)$ & $2.215(2)$ & $\mathrm{O}(1)-\mathrm{C}(9)$ & $1.135(7)$ \\
$\mathrm{Cr}-\mathrm{C}(5)$ & $2.213(2)$ & $\mathrm{O}(2)-\mathrm{C}(10)$ & $1.161(6)$ \\
$\mathrm{Cr}-\mathrm{C}(6)$ & $2.210(3)$ & $\mathrm{O}(3)-\mathrm{C}(11)$ & $1.133(8)$ \\
$\mathrm{Cr}-\mathrm{C}(7)$ & $2.209(3)$ & $\mathrm{C}(1)-\mathrm{C}(2)$ & $1.552(8)$ \\
$\mathrm{Cr}-\mathrm{C}(8)$ & $2.210(3)$ & $\mathrm{C}(2)-\mathrm{C}(3)$ & $1.513(7)$ \\
$\mathrm{Cr}-\mathrm{C}(9)$ & $1.841(5)$ & $\mathrm{M}(3) \cdots \mathrm{H}(2) 1^{a}$ & 3.46 \\
$\mathrm{Cr}-\mathrm{C}(10)$ & $1.841(5)$ & $\mathrm{M}(2) \cdots \mathrm{H}\left(1^{\prime}\right)^{a}$ & 2.80 \\
$\mathrm{~B}$-nd angles/ & & & \\
$\mathrm{C}(10)-\mathrm{Cr}-\mathrm{C}(11)$ & $88.7(3)$ & $\mathrm{Cr}-\mathrm{C}(9)-\mathrm{O}(1)$ & $179.5(5)$ \\
$\mathrm{C}(9)-\mathrm{Cr}-\mathrm{C}(11)$ & $89.6(3)$ & $\mathrm{Cr}-\mathrm{C}(10)-\mathrm{O}(2)$ & $176.3(5)$ \\
$\mathrm{C}(9)-\mathrm{Cr}-\mathrm{C}(10)$ & $88.8(2)$ & $\mathrm{Cr}-\mathrm{C}(11)-\mathrm{O}(3)$ & $178.0(6)$
\end{tabular}

Torsion angles/

\begin{tabular}{lrlr}
$\mathrm{C}(2)-\mathrm{C}(1)-\mathrm{C}\left(1^{\prime}\right)-\mathrm{C}(8)$ & 26 & $\mathrm{C}(6)-\mathrm{P}-\mathrm{Cr}-\mathrm{C}(9)^{b}$ & -10 \\
$\mathrm{H}(1)-\mathrm{C}(1)-\mathrm{C}(2)-\mathrm{H}(2 \mathrm{a})$ & 32 & $\mathrm{C}(4)-\mathrm{P}-\mathrm{Cr}-\mathrm{C}(11)^{b}$ & -13 \\
$\mathrm{H}(1)-\mathrm{C}(1)-\mathrm{C}(2)-\mathrm{H}(2 \mathrm{~b})$ & 157 & $\mathrm{C}(8)-\mathrm{P}-\mathrm{Cr}-\mathrm{C}(13)^{b}$ & -10 \\
\hline
\end{tabular}

${ }^{a} \mathrm{M}(\mathrm{n})$ indicates the location of the middle point of the corresponding $\mathrm{C} \equiv \mathrm{O}(\mathrm{n})$ group. ${ }^{b}$ Idealized torsion angles about the normal to the benzene ring passing through the $\mathrm{Cr}$ atoms; $\mathrm{P}$ indicates the location of the centre of the benzene ring.

group (its middle point) is at $2.83 \AA$ from the methylene antihydrogen $\mathrm{H}(2 \mathrm{a})$ (see Table 6). The $\mathrm{Cr}(\mathrm{CO})_{3}$ group shows a relevant 'slippage' (ca. $0.12 \AA$ ) towards the outer $\mathrm{C}(4)-\mathrm{C}(5)$ benzene bond.

As to the conformation $\mathbf{B}$ of the ligand we similarly expect that: (a) the five membered rings are puckered towards the convex side of the molecule, thus flattening its overall shape; $(b)$ the orientation of the methine hydrogen atom $\mathrm{H}(1)$ with respect to the adjacent methylene hydrogen atoms $\mathrm{H}(2 \mathrm{a})$ and $\mathrm{H}(2 \mathrm{~b})$ are defined by $\sigma_{1}=\mathrm{H}(1)-\mathrm{C}(1)-\mathrm{C}(2)-\mathrm{H}(1 \mathrm{a})=20-30^{\circ}$ and $\sigma_{1}=$ $\mathrm{H}(1)-\mathrm{C}(1)-\mathrm{C}(2)-\mathrm{H}(2 \mathrm{~b})=150-160^{\circ}$; [the same holds for the above mentioned $\sigma_{1}^{\prime}$ and $\sigma_{2}^{\prime}$, respectively]; (c) the syn-hydrogen atoms of the methylene groups $\mathrm{H}(2 \mathrm{~b})$ and $\mathrm{H}\left(2^{\prime} \mathrm{b}\right)$ get closer to each other and to the central normal to the adjacent benzene ring; $(d)$ the anti-hydrogen atoms of the methylene groups $\mathrm{H}(2 \mathrm{a})$ and $\mathrm{H}\left(2^{\prime} \mathrm{a}\right)$ and the methine hydrogens $\mathrm{H}(1)$ and $\mathrm{H}\left(1^{\prime}\right)$ move further away from each other.

According to point (c), for this conformation no syncomplexation with $\mathrm{Cr}(\mathrm{CO})_{3}$ is possible. Moreover, for an anticomplexation both the exo- and the endo-staggered conformations of the $\operatorname{Cr}(\mathrm{CO})_{3}$ tripod seem strongly hindered mainly by the methine hydrogens which are now much closer to the central normal to the benzene ring concerned. Therefore, an eclipsed conformation is still favoured. The $\mathrm{X}$-ray structural data for the anti-anti-bis- $\left[\mathrm{Cr}(\mathrm{CO})_{3}\right]_{2}$ di-indan complex confirms these arguments (see Fig. 4 and Table 7). The molecule lies on a twofold crystallographic axis. The $\mathrm{Cr}(\mathrm{CO})_{3}$ tripods are rotated $c a .10^{\circ}$ from an idealized eclipsed conformation, giving rise, here too, to a distance from the middle point of the $\mathrm{C}(10)-\mathrm{O}(2)$ bond to $\mathrm{H}\left(1^{\prime}\right)$ of $c a .2 .8 \AA$; no slippage is observed for $\mathrm{Cr}$. The NMR results (vide infra) are in agreement with these data and confirm the features $(b)$ and $(c)$ for both the mono- and bis-anticomplexes.

All the other geometrical parameters for the two complexes are quite normal and do not require particular comments. They are filed as supplementary material [sup. pub. no. 56881 (3 pp.)].*

NMR Results.-The discussion of the NMR data will be split into two parts, one concerning the resonances due to the aromatic and the other to the aliphatic portion of the molecules, respectively. The comparison of the NMR spectra of the two mono-complexed species shows that the signals of the complexed ring protons of 1 appear on average at lower field with respect to the corresponding signals of 2 (see Fig. 1). In addition, the chemical shift value of the ${ }^{13} \mathrm{C} \equiv \mathrm{O}$ nuclei of 1 occurs at $c a$. $1 \mathrm{ppm}$ downfield from that of 2 . By comparison with the analogous findings for the mono-complexed MTBTs, ${ }^{4}$ we conclude that in 1 the $\mathrm{Cr}(\mathrm{CO})_{3}$ group is bonded to the convex side of the ligand, and in 2 to the concave one. Additional confirmation of this assignment comes from the comparison with the NMR data of the bis-complexes (see below). Therefore, the relative position of the carbonyl ${ }^{13} \mathrm{C}$ signals represents again a valuable diagnostic tool which can help to determine the site of complexation when the $\mathrm{X}$-ray structure is not available.

The chemical shift values of the ${ }^{1} \mathrm{H}$ and ${ }^{13} \mathrm{C}$ nuclei of the uncomplexed benzene ring both in 1 and in 2 do not differ substantially from the corresponding values in the ligand, suggesting a negligible importance of long-range complexation effects.

Similar features are shown by the aromatic nuclei in the biscomplexed species, 3 and $\mathbf{4}$, the molecular structure of which has been obtained by X-ray analysis. In particular, it is evident (cf. Table 2 and Fig. 1) that the proton spectrum of the aromatic part of the antianti complex 4 is almost identical (both in chemical shift values and in signal shape) to that shown by the complexed ring of the anti-1 species. Moreover, the spectrum of the unsymmetrical syn,anti complex 3 in the range $\delta 6.1-5.3$ can be roughly obtained by superimposition of the complexed

* For details of the Supplementary Publications Scheme, see 'Instructions for Authors,' J. Chem. Soc., Perkin Trans. 2, 1992, Issue 1. 
ring proton signals of the 1 and 2 mono-complexes. A similar situation is also observed in the corresponding ${ }^{13} \mathrm{C}$ spectra. The two different chemical shift values of the $\mathrm{C} \equiv \mathrm{O}$ in 3 are very close to those observed in $\mathbf{1}$ and $\mathbf{2}$, respectively, suggesting that the two indan moieties behave as non-interacting entities in each case. The $\mathrm{C} \equiv \mathrm{O}$ resonance for 4 is shifted slightly upfield with respect to those of the other anti-Cr(CO) $)_{3}$ groups (in 1 and 3 ).

A careful examination of the ${ }^{1} \mathrm{H}$ NMR characteristics of the alicyclic part of the free and complexed DIN ligands affords a number of structural data, which can be profitably compared with the results of the X-ray diffraction studies.

Let us consider first the values (Table 3 ) of the ${ }^{3} J_{\mathrm{H}, \mathrm{H}}$ coupling constants shown by the methine $\mathrm{H}(1)$ [and $\mathrm{H}\left(1^{\prime}\right)$ ] protons with the endo-methylene protons $\mathrm{H}(2 \mathrm{~b})$ [and $\left.\mathrm{H}\left(2^{\prime} \mathrm{b}\right)\right]$. On the basis of the Karplus relation ${ }^{7}$ the smaller ${ }^{3} J_{\mathbf{H}(1), \mathbf{H}(2 \mathrm{~b})}$ and ${ }^{3} J_{\mathrm{H}\left(1^{\prime}\right), \mathrm{H}\left(2^{\prime} \mathrm{b}\right)}$ values (ranging from 1.29-1.97 Hz) found for the ligand and the complexes 2 and $\mathbf{3}$, respectively, suggest for these molecules a $\sigma_{2}$ angle close to $90^{\circ}$ (conformation $\mathbf{A}$, see above). On the other hand, the high value $(8.08 \mathrm{~Hz})$ found for 4 is indicative of a $\sigma_{2}$ value near to $180^{\circ}$ (conformation $\mathbf{B}$ ). Thus, the values measured by X-ray analysis for 3 and $4\left(\sigma_{2}=101^{\circ}\right.$ and $153^{\circ}$, respectively; Tables 6 and 7) are in good agreement with the NMR spectroscopic results. These findings suggest that, in solution, the conformation $\mathbf{A}$ is that adopted by the free ligand and the complexes 2 and 3 . The intermediate values of ${ }^{3} J_{\mathrm{H}(1), \mathrm{H}(2 \mathrm{~b})}(3.93 \mathrm{~Hz})$ and ${ }^{3} J_{\mathrm{H}\left(1^{\prime}\right), \mathrm{H}\left(2^{\prime} \mathrm{b}\right)}(3.90 \mathrm{~Hz})$ found for 1 indicate that in this case an intermediate conformation is preferred.

The high values $(7.46-9.39 \mathrm{~Hz})$ of the ${ }^{3} J_{\mathrm{H}, \mathrm{H}}$ coupling constants between the methine $\mathrm{H}(1)$ and $\mathrm{H}\left(1^{\prime}\right)$ protons and the anti-methylene protons $\mathrm{H}(2 \mathrm{a})$ and $\mathrm{H}\left(2^{\prime} \mathrm{a}\right)$ found for all these molecules are again in accordance with the dihedral angles $\mathrm{H}(1)-\mathrm{C}(1)-\mathrm{C}(2)-\mathrm{H}(2 \mathrm{a})$ and $\mathrm{H}\left(1^{\prime}\right)-\mathrm{C}\left(1^{\prime}\right)-\mathrm{H}\left(2^{\prime} \mathrm{a}\right)$ obtained by the $\mathrm{X}$-ray analysis both for 3 and $4\left(17^{\circ}\right.$ and $30^{\circ}$, respectively).

Further support for these considerations comes from the comparison between the diffractometric analysis and some selected $\left\{{ }^{1} \mathrm{H}\right\}-{ }^{1} \mathrm{H}$ Nuclear Overhauser Enhancement (NOE) data. In fact, the crystallographic data show that in the conformation $A$ the methylene $\mathbf{H}(2 \mathrm{~b})$ and $\mathbf{H}\left(2^{\prime} \mathrm{b}\right)$ syn-hydrogen atoms are very close to the $\mathrm{H}\left(7^{\prime}\right)$ and $\mathrm{H}(7)$ nuclei, respectively. On the other hand, the rotation around the $\mathrm{C}(1)-\mathrm{C}\left(1^{\prime}\right)$ bond giving rise to the conformation $\mathbf{B}$ causes these nuclei to become noticeably farther from each other. In the NOE experiments, a line enhancement for the $\mathrm{H}(7)$ and $\mathrm{H}\left(7^{\prime}\right)$ protons in the range of 6.4 $9.8 \%$ is observed upon saturation of the $H\left(2^{\prime} b\right)$ and $H(2 b)$ nuclei, respectively, of the ligand and the complexes $\mathbf{2}$ and $\mathbf{3}$; on the other hand the line enhancement decreases to $2.0 \%$ in 4 , and an intermediate value $(4.5 \%)$ is found for 1 .

\section{Conclusions}

Four complexes, 1-4, have been obtained by reacting $4 b, 5,9 b, 10-$ tetrahydro[2,1-a]indene with $\mathrm{Cr}(\mathrm{CO})_{6}$. From the combination of the X-ray and NMR spectroscopic data, it is concluded that the complexes 2 and 3 , both bearing a $s y n-\mathrm{Cr}(\mathrm{CO})_{3}$ unit, adopt the highly bent conformation $\mathbf{A}$ both in the solid state and in solution. The same holds for the free ligand in solution. By contrast, the twofold anti complexation in $\mathbf{4}$ gives rise to a conformational switch of the DIN unit into the 'stretched', less bent, conformation $\mathrm{B}$. With a single anti- $\mathrm{Cr}(\mathrm{CO})_{3}$ group in complex 1 , the conformational response of the DIN ligand to abandon the more favourable conformation $\mathbf{A}$ is much less pronounced.

Although the anti- $\mathrm{Cr}(\mathrm{CO})_{3}$ complexation seems kinetically favoured, the reluctance of the mono-anti complex 1 towards secondary complexation is remarkable, in contrast to the higher reactivity of the mono-syn stereoisomer 2 . Obviously, the steric interactions in the conformers $\mathbf{A}$ and $\mathbf{B}$ strongly govern the course of the secondary complexation. Further studies on $\mathrm{Cr}(\mathrm{CO})_{3}$ complexes with centro-polyindans ${ }^{3}$ are currently in progress in our laboratories.

\section{Experimental}

General--All the reactions and complex manipulation were performed in an oxygen-free argon atmosphere. The solvents were carefully dried and deoxygenated before use and the $\mathrm{Cr}(\mathrm{CO})_{6}$ reagent (Aldrich) was sublimed twice under reduced pressure just before use. Solvent mixtures, reaction times, and substrate/complexing agent ratios are given in Table 1 . The percentages of complexation products were determined by integration of the corresponding signal in the ${ }^{1} \mathrm{H}$ NMR spectra of the crude reaction mixtures. In the preparative experiments, the pure products were obtained by flash chromatography of the residue on silica after removal of the solvents. All the complexes appear as yellow, air-stable microcrystalline powders, which gave satisfactory combustion analyses. Melting points are uncorrected. Microanalyses were performed by $\mathrm{Mr}$. L. Turiaco, Dipartimento di Chimica Inorganica, Metallorganica ed Analitica, Università di Padova. The IR spectra were recorded as tetrahydrofuran (THF) solutions with a Perkin-Elmer 580B spectrophotometer, and the $70 \mathrm{eV}$ electron impact mass spectra were measured with a VG 16 MicroMass spectrometer.

Complex 1. M.p. $104-105^{\circ} \mathrm{C} ; v_{\max }(\mathrm{THF}) / \mathrm{cm}^{-1} 1959 \mathrm{vs}, 1887 \mathrm{vs}$ and $1876 \mathrm{vs}(\mathrm{C} \equiv \mathrm{O}) ; \mathrm{m} / \mathrm{z} 342\left(\mathrm{M}^{+}, 11.4 \%\right), 286\left(\mathrm{M}^{+}-2 \mathrm{CO}\right.$, 14.5), $258\left(\mathrm{M}^{+}-3 \mathrm{CO}, 100\right), 206\left[\mathrm{M}^{+}-(\mathrm{Cr}, 3 \mathrm{CO}), 3.4\right]$ and $52\left(\mathrm{Cr}^{+}, 75.5\right)$.

Complex 2. M.p. $152-153{ }^{\circ} \mathrm{C} ; v_{\max }(\mathrm{THF}) / \mathrm{cm}^{-1} 1961 \mathrm{vs}, 1891 \mathrm{vs}$ and $1879 \mathrm{vs}(\mathrm{C} \equiv \mathrm{O}) ; m / z 342\left(\mathrm{M}^{+}, 9.7 \%\right), 286\left(\mathrm{M}^{+}-2 \mathrm{CO}, 0.8\right)$, $258\left(\mathrm{M}^{+}-3 \mathrm{CO}, 100\right), 206\left[\mathrm{M}^{+}-(\mathrm{Cr}, 3 \mathrm{CO}), 2.2\right]$ and $52\left(\mathrm{Cr}^{+}\right.$, $62.8)$.

Complex 3. M.p. $175^{\circ} \mathrm{C}$ (decomp.); $v_{\max }(\mathrm{THF}) / \mathrm{cm}^{-1} 1961 \mathrm{vs,}$ $1958 \mathrm{vs}, 1891 \mathrm{vs}, 1882 \mathrm{vs}$ and $1872 \mathrm{vs}(\mathrm{C} \equiv \mathrm{O}) ; m / z 478\left(\mathrm{M}^{+}, 11.6^{\circ} \%\right)$, $422\left(\mathrm{M}^{+}-2 \mathrm{CO}, 3.2\right)$; $394\left(\mathrm{M}^{+}-3 \mathrm{CO}, 12.8\right), 366\left(\mathrm{M}^{+}-\right.$ $4 \mathrm{CO}, 5.7), 338\left(\mathrm{M}^{+}-5 \mathrm{CO}, 10.8\right), 310\left(\mathrm{M}^{+}-6 \mathrm{CO}, 10.1\right) 258$ $\left[\mathrm{M}^{+}-(\mathrm{Cr}, 6 \mathrm{CO}), 100\right], 202\left[\mathrm{M}^{+}-(2 \mathrm{Cr}, 6 \mathrm{CO}), 2.2\right]$ and 52 $\left(\mathrm{Cr}^{+}, 86.2\right)$

Complex 4. M.p. $175^{\circ} \mathrm{C}$ (decomp.); $v_{\max }(\mathrm{THF}) / \mathrm{cm}^{-1} 1968 \mathrm{vs,}$ $1957 \mathrm{vs}, 1891 \mathrm{vs}, 1885 \mathrm{vs}$ and $1877 \mathrm{vs}(\mathrm{C} \equiv \mathrm{O}) ; \mathrm{m} / z 478\left(\mathrm{M}^{+}, 20.7 \%\right)$, $422\left(\mathrm{M}^{+}-2 \mathrm{CO}, 4.3\right) ; 394\left(\mathrm{M}^{+}-3 \mathrm{CO}, 28.3\right), 366\left(\mathrm{M}^{+}-\right.$ $4 \mathrm{CO}, 12.4), 338\left(\mathrm{M}^{+}-5 \mathrm{CO}, 43.2\right), 310\left(\mathrm{M}^{+}-6 \mathrm{CO}, 30.2\right)$, $286\left[\mathrm{M}^{+}-(\mathrm{Cr}, 5 \mathrm{CO}), 2.5\right], 258\left[\mathrm{M}^{+}-(\mathrm{Cr}, 6 \mathrm{CO}), 100\right], 202$ $\left[\mathrm{M}^{+}-(2 \mathrm{Cr}, 6 \mathrm{CO}), 3.4\right]$ and $52\left(\mathrm{Cr}^{+}, 89.7\right)$.

Collection of NMR Data.-Appropriate $20-40 \mathrm{mmol} \mathrm{dm}^{-3}$ solutions for both ${ }^{1} \mathrm{H}$ and ${ }^{13} \mathrm{C}$ NMR spectroscopic measurements were obtained by using carefully dried, oxygen-free $\left[{ }^{2} \mathrm{H}_{6}\right]$ acetone. The proton spectra, recorded on a Bruker AM400 spectrometer operating at $400.133 \mathrm{MHz}$, were analysed using the Bruker PANIC program on a Bruker Aspect 2000 computer. The proton-decoupled $100.614 \mathrm{MHz}{ }^{13} \mathrm{C}$ NMR spectra were obtained with the same solutions by using a $6 \mathrm{~s}$ delayed Waltz-like CPD decoupling technique with full recover of the Overhauser line enhancement to get satisfactory signal-tonoise ratios after $128-256$ accumulations on a $64 \mathrm{~K}$ word size.

Collection of X-Ray Diffraction Data.-Single crystals of 3 and 4 were grown under argon from a saturated solution in a 1:1:1 mixture of carefully dried, oxygen-free acetone, methanol and methylene dichloride. They were mounted on a Philips PW-100 computer-controlled four-circle diffractometer with graphite monochromator. Standard centring and autoindexing procedures ${ }^{8}$ indicated a primitive monoclinic lattice, space group $P 2_{1} / a$ for 3 and a centred monoclinic lattice, space group $C 2 / c$ for 4 . The orientation matrix and accurate unit cell 
Table 8 Fractional coordinates for the complexes 3 and 4

\begin{tabular}{|c|c|c|c|}
\hline Atom & $x$ & $y$ & $z$ \\
\hline \multicolumn{4}{|c|}{ Complex 3} \\
\hline $\operatorname{Cr}(1)$ & $0.17228(8)$ & $0.2253(1)$ & $0.0845(1)$ \\
\hline $\mathrm{Cr}(2)$ & $-0.06134(9)$ & $0.2137(1)$ & $-0.4004(1)$ \\
\hline$O(1)$ & $0.1944(7)$ & $0.152(1)$ & $0.3458(9)$ \\
\hline $\mathrm{O}(2)$ & $0.3588(4)$ & $0.2219(8)$ & $0.11032(8)$ \\
\hline $\mathrm{O}(3)$ & $0.1806(5)$ & $0.4834(7)$ & $0.1703(9)$ \\
\hline $\mathrm{O}(4)$ & $0.0277(5)$ & $-0.0138(6)$ & $-0.3007(7)$ \\
\hline$O(5)$ & $-0.1460(5)$ & $0.1998(8)$ & $-0.1460(5)$ \\
\hline $\mathrm{O}(6)$ & $-0.1963(6)$ & $0.0574(9)$ & $-0.5388(8)$ \\
\hline$C(1)$ & $0.067(1)$ & $0.420(1)$ & $-0.218(1)$ \\
\hline$C(2)$ & $0.032(1)$ & $0.400(1)$ & $-0.014(1)$ \\
\hline$C(3)$ & $0.0666(4)$ & $0.2774(5)$ & $-0.0636(6)$ \\
\hline$C(4)$ & $0.0401(4)$ & $0.2006(5)$ & $0.0213(6)$ \\
\hline$C(5)$ & $0.0774(4)$ & $0.0871(5)$ & $0.0468(6)$ \\
\hline$C(6)$ & $0.1410(4)$ & $0.0504(5)$ & $-0.0126(6)$ \\
\hline$C(7)$ & $0.1674(4)$ & $0.1272(5)$ & $-0.1974(6)$ \\
\hline $\mathrm{C}(8)$ & $0.1302(4)$ & $0.2407(5)$ & $-0.1230(6)$ \\
\hline$C\left(1^{\prime}\right)$ & $0.1246(6)$ & $0.3375(9)$ & $-0.222(1)$ \\
\hline$C\left(2^{\prime}\right)$ & $0.1445(9)$ & $0.280(1)$ & $-0.345(1)$ \\
\hline$C\left(3^{\prime}\right)$ & $0.0593(4)$ & $0.3081(7)$ & $-0.4038(8)$ \\
\hline $\mathrm{C}\left(4^{\prime}\right)$ & $0.0261(4)$ & $0.2644(7)$ & $-0.5208(8)$ \\
\hline$C\left(5^{\prime}\right)$ & $-0.0548(4)$ & $0.2956(7)$ & $-0.5769(8)$ \\
\hline$C\left(6^{\prime}\right)$ & $-0.1024(4)$ & $0.3705(7)$ & $-0.5161(8)$ \\
\hline$C\left(7^{\prime}\right)$ & $-0.0692(4)$ & $0.4142(7)$ & $-0.0692(4)$ \\
\hline $\mathrm{C}\left(8^{\prime}\right)$ & $0.0117(4)$ & $0.3830(7)$ & $-0.3430(8)$ \\
\hline $\mathrm{C}(9)$ & $0.1857(7)$ & $0.181(1)$ & $0.244(1)$ \\
\hline$C(10)$ & $0.2851(6)$ & $0.2219(8)$ & $0.0989(9)$ \\
\hline$C(11)$ & $0.1773(5)$ & $0.385(1)$ & $0.135(1)$ \\
\hline$C(12)$ & $-0.0041(7)$ & $0.0754(9)$ & $-0.339(1)$ \\
\hline$C(13)$ & $-0.1135(6)$ & $0.2068(8)$ & $-0.267(1)$ \\
\hline$C(14)$ & $-0.1442(7)$ & $0.118(1)$ & $-0.4858(9)$ \\
\hline \multicolumn{4}{|c|}{ Complex 4} \\
\hline $\mathrm{Cr}$ & $0.37437(3)$ & $0.12778(8)$ & $0.08749(4)$ \\
\hline $\mathrm{O}(1)$ & $0.3186(3)$ & $-0.1068(6)$ & $-0.0622(3)$ \\
\hline $\mathrm{O}(2)$ & $0.4498(2)$ & $-0.2126(5)$ & $0.1632(3)$ \\
\hline $\mathrm{O}(3)$ & $0.2457(3)$ & $0.0379(9)$ & $0.1919(4)$ \\
\hline$C(1)$ & $0.4774(2)$ & $0.2252(4)$ & $0.2934(2)$ \\
\hline $\mathrm{C}(2)$ & $0.4169(2)$ & $0.3701(5)$ & $0.2738(3)$ \\
\hline$C(3)$ & $0.4091(1)$ & $0.3645(3)$ & $0.1738(1)$ \\
\hline$C(4)$ & $0.3529(1)$ & $0.4274(3)$ & $0.1192(1)$ \\
\hline$C(5)$ & $0.3572(1)$ & $0.4093(3)$ & $0.0274(1)$ \\
\hline$C(6)$ & $0.4177(1)$ & $0.3287(3)$ & $-0.0098(1)$ \\
\hline$C(7)$ & $0.4740(1)$ & $0.2658(3)$ & $0.0447(1)$ \\
\hline$C(8)$ & $0.4696(1)$ & $0.2837(3)$ & $0.1365(1)$ \\
\hline$C(9)$ & $0.3401(2)$ & $-0.0180(7)$ & $-0.0049(3)$ \\
\hline$C(10)$ & $0.4183(3)$ & $-0.0834(6)$ & $0.1341(3)$ \\
\hline$C(11)$ & $0.2948(3)$ & $0.0694(9)$ & $0.1505(4)$ \\
\hline
\end{tabular}

dimensions were determined from a least square fit of 25 symmetry-related reflections. The intensities were corrected for Lorentz and polarization effects but not for absorption owing to the relative low $\mu$ values. Crystal data and details of intensity data collection appear in Table 4. The position of the $\mathrm{Cr}$ atoms were determined from a three-dimensional Patterson syntheses. The light atoms were located from subsequent Fourier maps. The positions of the hydrogen atoms were determined from the least difference-Fourier maps; they were assigned the isotropic thermal parameters $\left[U(\mathrm{H})=1.2 U_{\mathrm{eq}}(\mathrm{H})\right]$ of the parent carbon atom introduced in the final calculations but were not refined. Anisotropic thermal parameters were used for all the nonhydrogen atoms. Blocked-cascade least-square refinements were used. They converged to the conventional $R$ indexes reported in Table 4. An unitary weighting scheme was used. Scattering factors for the atoms were taken from Cromer and Waber, ${ }^{9}$ the scattering factors for the $\mathrm{Cr}$ were corrected for the real and imaginary parts of anomalous dispersion using Cromer's values. ${ }^{10}$ All computations were carried out on a Cyber 76 computer using the SHELX-76 program. ${ }^{11}$ The final positional parameters of the non-hydrogen atoms are listed in Table 8. Tables of thermal parameters, the positional parameters of the hydrogen atoms and full lists of bond lengths and angles for $\mathbf{3}$ and $\mathbf{4}$ have been deposited at the Cambridge Crystallographic Data Centre.*

\section{Acknowledgements}

This work was supported in part by the National Research Council of Italy (CNR) through its Centro di Studio sugli Stati Molecolari, Radicalici ed Eccitati. Support by the Deutsche Forschungsgemeinschaft (DFG, Ku 663 1-1) is gratefully acknowledged. Discussions with Professor T. E. Bitterwolf, University of Idaho, are gratefully appreciated.

* For details of the CCDC deposition scheme, see 'Instruction for Authors', J. Chem. Soc., Perkin Trans. 2, 1992, Issue 1.

\section{References}

1 R. U. Kirss, P. M. Treichel and K. J. Haller, Organometallics, 1987, 6, 242 , and references therein.

2 T. E. Bitterwolf, R. Herzog and P. D. Rockswold, J. Organomet. Chem., 1987, 320, 197; T. G. Traylor, M. J. Goldberg and A. R. Miksztal, Organometallics, 1989, 8, 1101.

3 (a) D. Kuck, in Quasicrystals, Networks, and Molecules of Fivefold Symmetry, ed. I. Hargittai, VCH Publisher, New York, 1990; ch. 19; (b) D. Kuck, Angew. Chem., Int. Ed Engl., 1984, 23, 508; (c) D. Kuck, T. Lindenthal and A. Schuster, Chem. Ber., 1992, in press.

4 A. Ceccon, A. Gambaro, F. Manoli, A. Venzo, D. Kuck, T. E. Bitterwolf, P. Ganis and G. Valle, J. Chem. Soc. Perkin Trans. 2, 1991, 233

5 (a) R. S. D. Mittal, S. C. Sethi and Sukh Dev, Tetrahedron, 1973, 29 1321; (b) F. Ogura, A. Nakao and M. Nakagawa, Bull. Soc. Chim. Japan, 1980, 53, 291

6 R. D. Rogers, J. L. Atwood, T. A. Albright, W. A. Lee and M. D. Rausch, Organometallics, 1984, 3, 263.

7 Karplus and Conroy, in H. Günther, NMR Spectroscopy-An Introduction, J. Wiley \& Son, New York, 1980, p. 106.

8 R. A. Sparks, in Crystallographic Computing Techniques, ed. F. R. Ahmed, Munksgaard, Copenhagen, 1976, p. 452.

9 D. T. Cromer and J. T. Waber, Acta Crystallogr., 1965, 18, 184

10 D. T. Cromer, Acta Crystallogr., 1965, 18, 17.

11 G. M. Sheldricks, SHELX-76, Program for Crystal Structure Determination, Cambridge University, England, 1976.

Paper $2 / 00063 \mathrm{~F}$

Received 6th January 1992 Accepted 26th February 1992 